\title{
Allelopathy of leaf extracts of jatropha (Jatropha curcas L.) in the initial development of wheat (Triticum aestivum L.)
}

\author{
La alelopatía de extractos de hojas de jatropha (Jatropha curcas L.) \\ en el desarrollo inicial del trigo (Triticum aestivum $L$.) \\ Tharyn Reichel ${ }^{1}$, Jéssica Fernanda Barazetti ${ }^{1}$, Suzana Stefanello ${ }^{1}$, Roberta Paulert ${ }^{1}$, \\ Patricia da Costa Zonetti ${ }^{1^{*}}$
}

\begin{abstract}
The objective of this study was to evaluate the effect of extracts obtained from leaves of Jatropha curcas L. on germination and initial growth of wheat. The aqueous and alcohol (ethanol and methanol) extracts of dried leaves were prepared in the concentration of $50 \mathrm{mg} / \mathrm{mL}$. From the crude extract were made dilutions and obtained different concentrations. Some of the aqueous extracts tested were autoclaved. Over seven days, the germination characteristics and growth of wheat seedlings were evaluated with the different treatments. There was no effect of aqueous extracts on percentage of seed germination, however the methanolic and ethanolic extracts $5 \%$ affected the germination of a cultivar in study. There was a decrease in the germination speed index when the seeds were incubated with crude aqueous extract and methanol extract. The extracts affected the growth of seedlings and the most phytotoxic was the ethanol extract 5\%. The autoclaved extracts promoted a reduction in all parameters evaluated. The results presented here show the extracts of dried leaves of jatropha promoted allelopathic effects on wheat.
\end{abstract}

Key words: extract, interference, germination, growth of seedlings.

\section{RESUMEN}

El objetivo de la investigación fue evaluar el efecto de los extractos obtenidos a partir de hojas de Jatropha curcas L. sobre la germinación y el crecimiento inicial del trigo. Las acuosas y alcohol (etanol y metanol) extractos de hojas secas se prepararon de la concentración de $50 \mathrm{mg} / \mathrm{ml}$. A partir del extracto crudo se hicieron diluciones, obteniendo diferentes concentraciones. Algunos de los extractos acuosos ensayados se trataron en autoclave. Durante siete días, las características de germinación y crecimiento de plántulas de trigo fueron evaluados con los diferentes tratamientos. No hubo efecto de extractos acuosos en el porcentaje de germinación de las semillas; sin embargo, los extractos metanólicos y etanólicos $5 \%$ afectaba la germinación de un cultivar en estudio. Hubo una disminución en el índice de velocidad de germinación cuando las semillas se incubaron con extracto crudo acuoso y extracto de metanol. Los extractos afectaron el crecimiento de las plántulas y el más fitotóxico era el extracto en etanol 5\%. Los extractos autoclave promovieron una reducción en todos los parámetros evaluados. Los resultados aquí presentados muestran los extractos de hojas secas de Jatropha que promueven efectos alelopáticos sobre el trigo.

Palabras clave: extracto, interferencia, germinación, crecimiento de las plántulas.

\section{Introduction}

Allelopathy can ensure the survival of different species in the ecosystem as can instigate studies with biomolecules on an industrial scale for the production of insecticides, herbicides and medicines.

The chemical compounds with allelopathic function are from the secondary metabolism of plants and can in this way, be useful in alternative managements in agriculture (Duke \& Dayan, 2006). Even with promising potential, allelopathy may cause economic damage in plantations, once the chemical compounds potentially used in the control of diseases and pests, for example, can interfere with the culture of interest (Chou, 1983).

Allelopathy is a phenomenon that occurs in nature, in which chemical substances are released by plants in the environment and can cause stimulatory or inhibitory effects in germination, growth and development of other nearby plants, which may interfere in many life processes of plants as the use of water and nutrient assimilation, growth of the

\footnotetext{
1 Federal University of Parana, Palotina Campus. Rua Pioneiro, 2153, Jd. Dallas, Palotina, Paraná. CEP: 85950-000.

* Corresponding Author: patriciazonetti@ufpr.br
} 
roots, in the expansion of leaves, in photosynthesis, synthesis of proteins, in cellular respiration and cell membrane permeability (Rice, 1984; Cruz-Ortega et al., 1988; Einhellig, 1995).

Jatropha (Jatropha curcas L.) is a perennial plant belonging to the family Euphorbiaceae, whose seed is used to extract oil that presents many different utilities, with the possibility of being used for the biodiesel production (Alves et al., 2008). The oil extracted from the seed presents toxic compounds as diterpenes with applications such as pesticides, insecticides, bactericides, nematicides and fungicides (Devappa et al., 2010). Among the main toxic substances present in jatropha are curcin and phorbol ester 12 - deoxy-16-hidroxiforbol (Beltrão \& Oliveira, 2008).

Reports show possible allelopathic action of jatropha. Thus, Lemos et al. (2009), observed interference of the aqueous extract of leaves in the initial development of lettuce. Bonamigo et al. (2009) report allelopathic effect of aqueous extract of root on the initial development of soybean and canola.

Faced the facilities of its cultivation, recent attention as a promising source of biofuel and few studies about allelopathy, this study aimed to evaluate the effect of aqueous and alcoholic extracts of leaves on the initial development of wheat.

\section{Materials and Methods}

\section{Plant Material}

The leaves of jatropha used in the preparation of the extracts were collected in the city of Palotina, PR, Brazil, in area of cultivation. The seeds of wheat cultivar Frontana and CD104 were kindly provided by the company COODETEC, Cascavel, PR.

\section{Obtaining Extracts}

The leaves of jatropha after being collected were air dried at $45{ }^{\circ} \mathrm{C}$ for 48 hours. Then, they were transferred to desiccator until the complete cooling. With the dry material were prepared crude extracts at a concentration of $50 \mathrm{mg} / \mathrm{mL}$.

For the preparation of crude aqueous extract the dried plant material was ground in a blender with the addition of distilled water and filtered in gauze and cotton. The treatments consisted of crude aqueous extract in different concentrations. To obtain the crude ethanolic and methanolic extracts, the plant material was finely grounded with ethanol or methanol, respectively. The plant material was in contact with the solvent during 72 hours and maceration was performed at intervals of 24 hours. The extracts were filtered with gauze and cotton, and then evaporated at reduced pressure using a rotary evaporator.

In order to evaluate the activity of the extracts on germination and development of wheat, the crude aqueous and alcoholics extracts were diluted in distilled water to obtain different concentrations. Thus, the crude aqueous extract was diluted in concentrations of $5,10,15,20,25,30$ and $35 \%$ $(\mathrm{v} / \mathrm{v})$. A fraction of the concentrations of 5, 10 and $15 \%$ of the aqueous extract was autoclaved to check the influence on germination and growth. On the other hand, the alcoholic extracts (methanolic and ethanolic) were also diluted in distilled water to obtain the concentrations of 1 and $5 \%$.

\section{Germination Test and Evaluation of the Initial Growth of Wheat}

Over seven days the germination characteristics and growth of seedling were evaluated. In the germination bioassay, fifty seeds of wheat were arranged in a Petri dish lined with germitest paper previously moistened with the extracts. As a control was used only distilled water. The germination percentage $(\mathrm{G} \%)$ and the germination speed index (GSI) were evaluated. For GSI were counted daily the number of seeds that showed protrusion of the seminal root with length $\geq 2 \mathrm{~mm}$. GSI was calculated by summing the number of germinated seeds each day, divided by the number of days between sowing and germination, according to Ferreira \& Borghetti (2004). In the growth biotest, twenty seeds were arranged with the edge of rootlet down in the center of the paper type germitest. After seven days, the air and the seminal root of normal seedlings were measured in length. The tests were conducted in a germination camera type B.O.D. at $23^{\circ} \mathrm{C}$ and photoperiod of 12 hours. The design was prepared entirely randomized and all treatments were replicated four times.

\section{Statistical Analysis}

Analysis of variance (ANOVA) and the differences between the parameters were evaluated by Dunnett or Scott Knott test. The values of $\mathrm{p} \leq 0.05$ 
when different of the control were considered statistically significant.

\section{Results and Discussion}

There was no significant effect of aqueous extract in different concentrations tested on the germination percentage $(\% \mathrm{G})$ of wheat seeds. However, there was a decrease in germination speed index (GSI) when both cultivars were maintained in the presence of crude aqueous extract (Figure 1A and B).
The alcoholic extracts at the highest concentration tested $(5 \%)$ promoted a reduction in the percentage of seed germination of wheat cultivar CD104 (Table 1). On the other hand, the alcoholic extracts tested did not interfere in the germination percentage of cultivar Frontana (Table 2). The speed of seeds germination was negatively affected only in the cultivar Frontana by methanol extract. The alcoholic extracts promoted greater allelopathic effect on the germination of wheat compared to the aqueous extracts even at higher concentration.

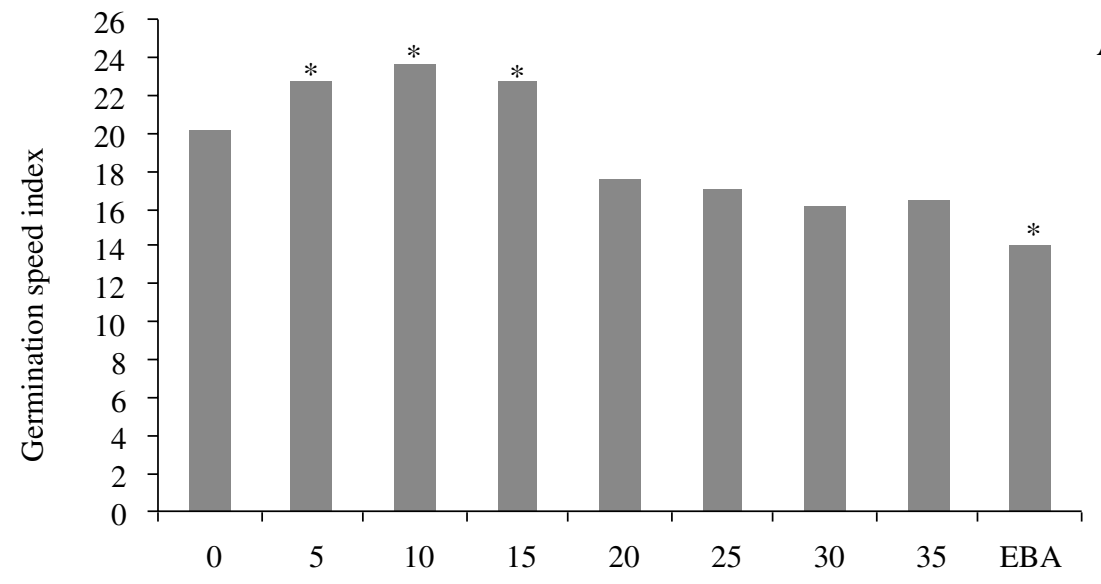

Different concentrations $(\%)$ of crude aqueous extract

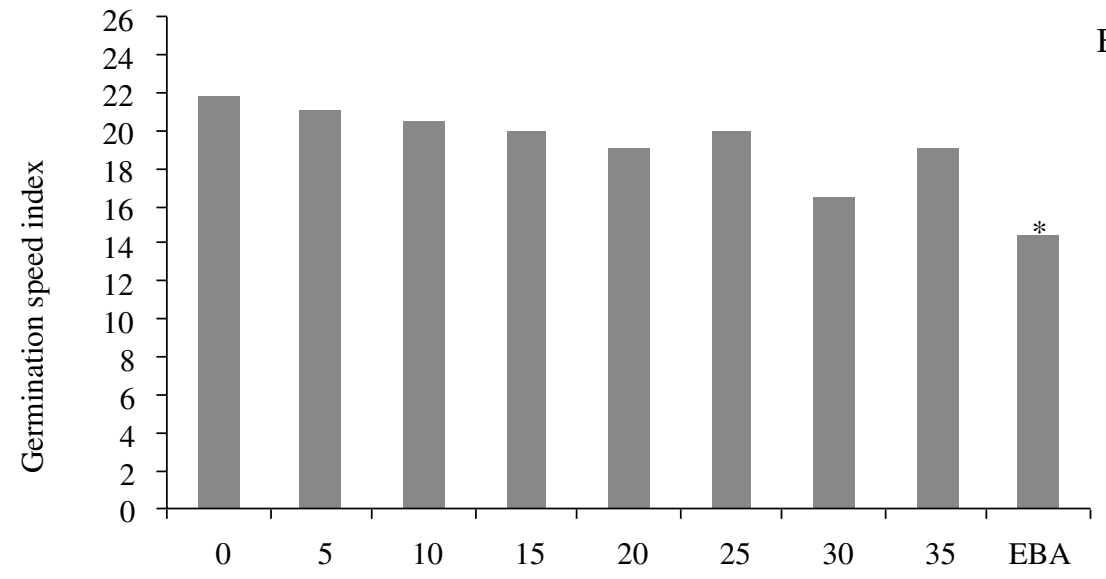

Different concentrations (\%) of crude aqueous extract

Figure 1. Germination speed index of wheat seeds (Triticum aestivum L.) cultivar CD 104 (A) and cultivar Frontana (B) germinated in filter paper with different concentrations of crude aqueous extract (EBA) of jatropha leaves (Jatropha curcas L.). Bar followed by $(*)$ is significantly different by Dunnett test at $5 \%$ probability. 
Table 1. Germination and seedling growth of wheat (Triticum aestivum L.) cultivar CD 104 germinated and grown in substrate containing alcoholic extracts (ethanol or methanol) of jatropha leaves (Jatropha curcas L.).

\begin{tabular}{lcccc}
\hline Treatments & $\% \mathrm{G}$ & GSI & Length shoot $(\mathrm{cm})$ & Length root $(\mathrm{cm})$ \\
\hline Control & $88 \mathrm{a}$ & $13.15 \mathrm{~b}$ & $8.35 \mathrm{a}$ & $13.87 \mathrm{a}$ \\
Ethanol $1 \%$ & $93 \mathrm{a}$ & $21.28 \mathrm{a}$ & $4.60 \mathrm{c}$ & $8.95 \mathrm{c}$ \\
Ethanol $5 \%$ & $64 \mathrm{~b}$ & $12.11 \mathrm{~b}$ & $2.85 \mathrm{~d}$ & $6.43 \mathrm{~d}$ \\
Methanol 1\% & $85 \mathrm{a}$ & $10.90 \mathrm{~b}$ & $8.98 \mathrm{a}$ & $11.50 \mathrm{~b}$ \\
Methanol 5\% & $75 \mathrm{~b}$ & $9.39 \mathrm{~b}$ & $6.15 \mathrm{~b}$ & $5.92 \mathrm{~d}$ \\
\hline C.V. $(\%)$ & 11.12 & 15.02 & 15.62 & 16.25 \\
\hline
\end{tabular}

C.V. = coefficient of variation; $\% \mathrm{G}=$ germination percentage; $\mathrm{GSI}=$ germination speed index.

Means comparisons within each column were compared by Scott-Knott test at $5 \%$ probability.

Table 2. Germination and seedling growth of wheat (Triticum aestivum L.) cultivar Frontana germinated and grown in filter paper containing alcoholic extracts (ethanol or methanol) of jatropha leaves (Jatropha curcas L.).

\begin{tabular}{lcccc}
\hline Treatments & $\% \mathrm{G}$ & GSI & Length shoot $(\mathrm{cm})$ & Length root $(\mathrm{cm})$ \\
\hline Control & $88.5 \mathrm{a}$ & $14.64 \mathrm{a}$ & $10.47 \mathrm{a}$ & $12.86 \mathrm{a}$ \\
Ethanol 1\% & $86.0 \mathrm{a}$ & $14.80 \mathrm{a}$ & $2.13 \mathrm{~b}$ & $2.40 \mathrm{~b}$ \\
Ethanol 5\% & $79.5 \mathrm{a}$ & $14.02 \mathrm{a}$ & $0.00 \mathrm{c}$ & $0.20 \mathrm{c}$ \\
Methanol 1\% & $87.5 \mathrm{a}$ & $10.74 \mathrm{~b}$ & $12.05 \mathrm{a}$ & $14.12 \mathrm{a}$ \\
Methanol 5\% & $81.5 \mathrm{a}$ & $9.04 \mathrm{~b}$ & $3.45 \mathrm{~b}$ & $2.97 \mathrm{~b}$ \\
\hline C.V. $(\%)$ & 8.07 & 11.46 & 13.63 & 16.32 \\
\hline
\end{tabular}

C.V. = coefficient of variation; $\% \mathrm{G}=$ germination percentage; $\mathrm{GSI}=$ germination speed index. Means comparisons within each column were compared by Scott-Knott test at 5\% probability.

* No growth.

Even if some treatments do not alter the G\%, was observed that the GSI of seeds was negatively affected by the crude aqueous extract and methanol extract in one of the cultivars in study. Similar results have been reported frequently in studies about allelopathy (Melo \& Gonçalves, 2001; França et al., 2008; Silva et al., 2009; Silva-Candido et al., 2010; Silva et al., 2011). According to Ferreira \& Borguetti (2004), the allelopathic effect on speed of germination is due to the interference that block or delay the progress of metabolic processes during the germination process. The GSI measures the time that the seeds take to germinate, so lower values of GSI represent delay in the germination process and, therefore, reductions in the time of germination may show that the presence of allelochemicals can decrease the speed of deployment and translocation of nutritional components of the endosperm to the embryo.

With respect to the growth of seedlings, the crude aqueous extract inhibited the growth of the seminal root of both cultivars as well as the shoot of cultivar Frontana (Figure 2). The concentrations of aqueous extract 20, 25, 30 and $35 \%$ stimulated the growth of the root of cultivar CD104. Similar result was observed in the growth of the shoot, except with the extract at a concentration of $20 \%$ (Figure 2).

The inhibition of the shoot growth was more pronounced in treatment with ethanolic extract $5 \%$ reaching to reduce $65.9 \%$ compared to control in the cultivar CD 104. This same treatment completely inhibited the growth of the shoot of cultivar Frontana (Table 2 and Figure 3). In the presence of alcoholic extracts, the shoot of the seedlings was more affected than the root (Tables 1 and 2).

In the test with the extracts autoclaved, was observed that the $\% \mathrm{G}$ and the GSI were negatively influenced (Table 3). In comparison with the control, the crude aqueous extract autoclaved caused a decline of $15.4 \%$ and $40.9 \%$ in $\%$ G and IVG, respectively. A similar result was verified by Muniz et al. (2007), who reported that there were lower values of germination in lettuce seeds subjected to autoclaved extracts of purple nutsedge (Cyperus rotundus). According to these authors, the lowest 


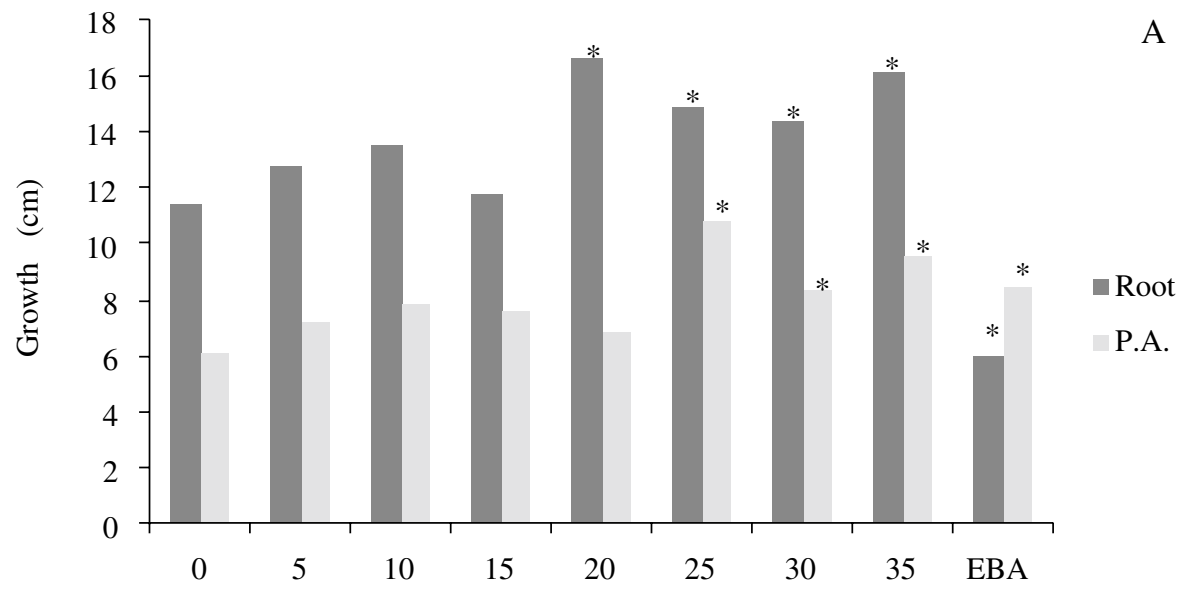

Different concentrations (\%) of crude aqueous extract

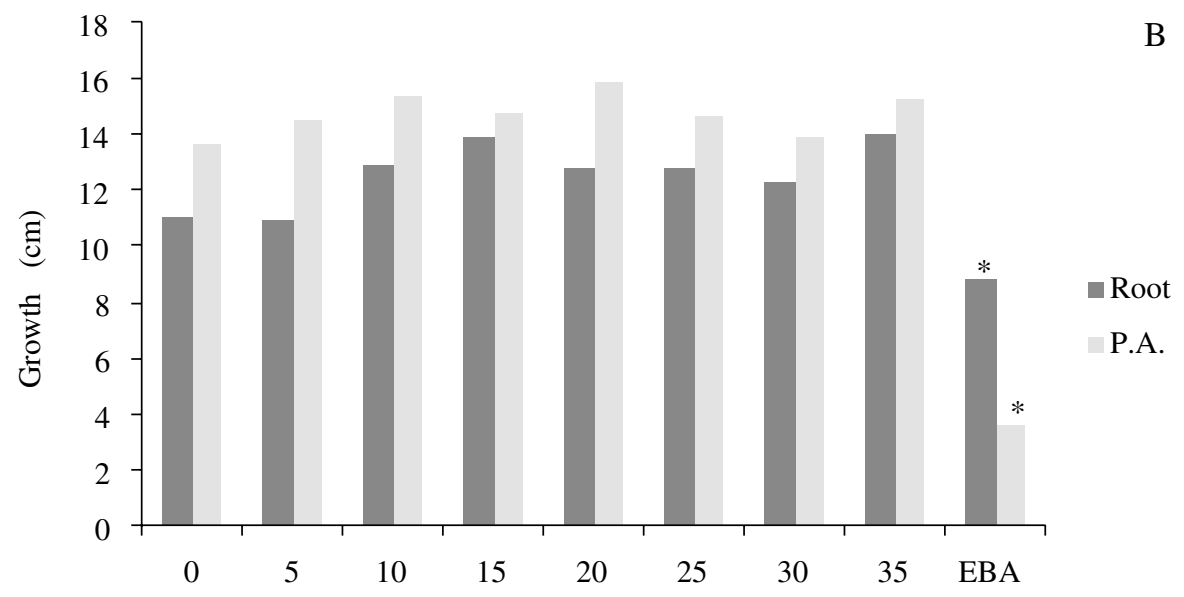

Different concentrations $(\%)$ of crude aqueous extract

Figure 2. Average growth of the seminal root and shoot (P.A.) of wheat seedlings (Triticum aestivum L.) cultivar CD 104 (A) and cultivar Frontana (B) grown seven days in filter paper in different concentrations of crude aqueous extract (EBA) of jatropha leaves (Jatropha curcas L.) leaves. Bars followed by (*) represents statistical difference by Dunnett test at $5 \%$ probability.

values of germination observed in the presence of the extracts autoclaved can be attributed to the higher concentration of the substance, as during the autoclaving can occur water loss.

The crude aqueous extract in different concentrations $(5,10$ and $15 \%)$, autoclaved or not, promoted reduction in the growth of shoot (Table 3). With the presence of the crude aqueous extract not autoclaved in the midst of growth of seedlings, there was an inhibition of approximately $73.3 \%$ in the length of the shoot when compared with the control group.
The extracts of jatropha leaves showed interference in the initial growth of wheat seedlings independent of the type of extraction and concentration of the extract. While the crude extracts inhibited the growth, in some lower concentrations of aqueous extract there was a stimulation of growth of cultivar CD 104. These results corroborate with those of Cruz-Silva et al. (2009) and Sausen et al. (2009).

The reduction in the growth of wheat seedlings in the presence of the different extracts tested was more drastic than on the germination of seeds. 


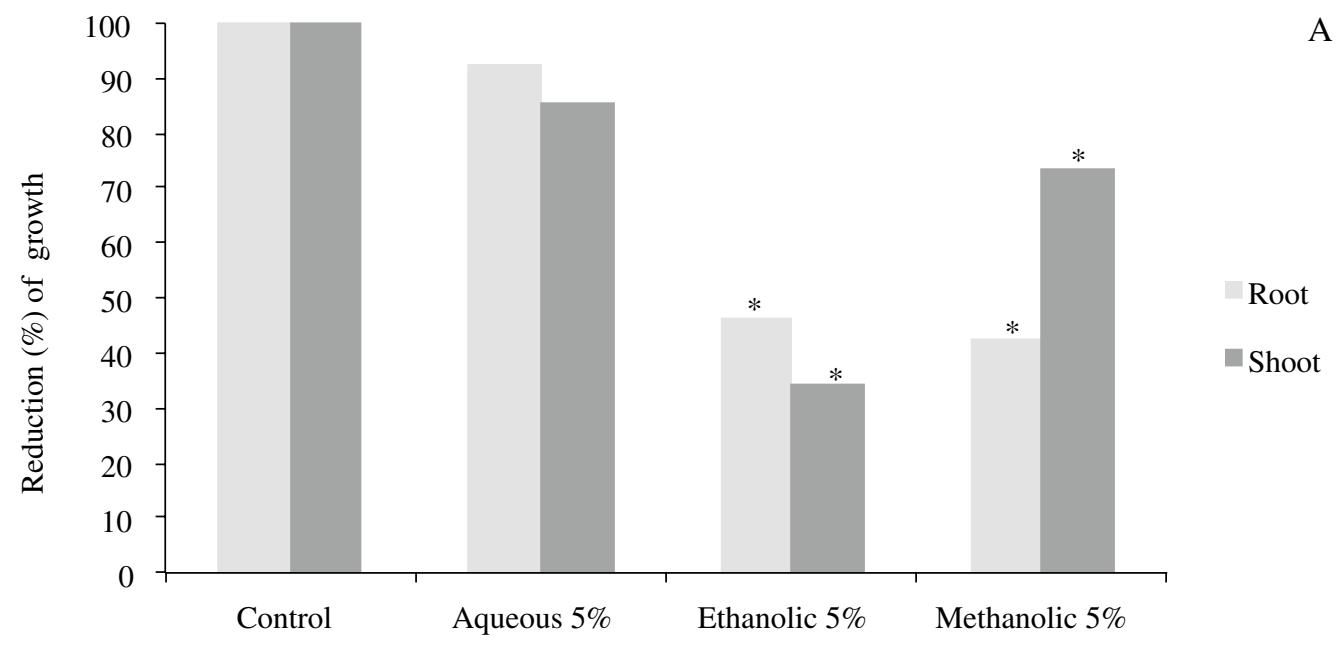

Treatments

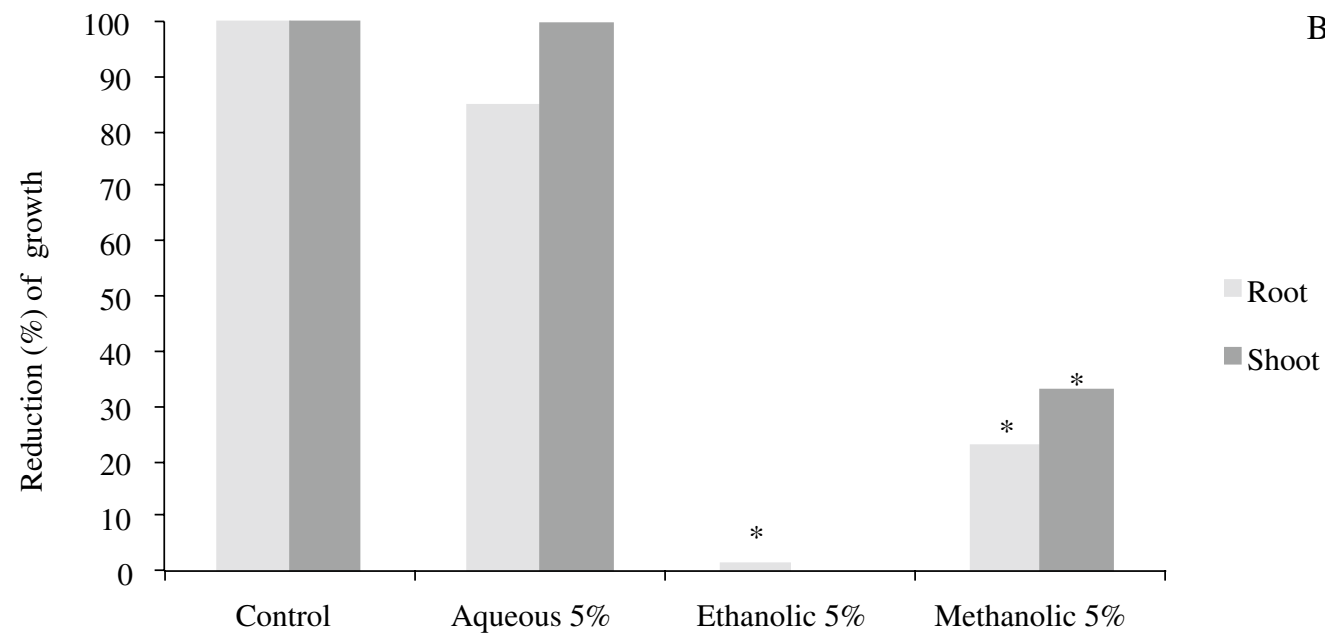

Treatments

Figure 3. Reduction of the of root and shoot growth (PA) (\%) of wheat seedlings (Triticum aestivum L.) cultivar CD 104 (A) and cultivar Frontana (B) grown in the presence of jatropha leaf (Jatropha curcas L.) extracts with the concentration of $5 \%$ from the inicial one of $50 \mathrm{mg} / \mathrm{mL}$. Bar followed by (*) is significantly different by Dunnett test at $5 \%$ probability.

Some studies have shown similar results (Periotto et al., 2004; Maraschin-Silva \& Áqüila, 2005; Silva-Candido et al., 2010; Pereira et al., 2011). According to Ferreira \& Aquila (2000) the germination is less sensitive to allelochemicals than the seedling growth, because the allelopathic substances may induce the appearance of abnormal seedlings, for example, with symptoms of necrosis in the root. Maraschin-Silva \& Aquila (2005) also indicate that the seed may suffer less due to the fact of the germination process uses their own seed reserves.
A

B

Studies attempting to assess the real impact of jatropha on the development of other plants in small properties as well as a possible source of extraction of molecules with chemical potential in the industry of chemicals defensive should be conducted.

\section{Conclusion}

The alcoholic extracts of the leaves of jatropha affected more dramatically the growth of the seedlings 
than the aqueous extract. The autoclaving process of the extracts promoted changes in these biological properties, reducing all parameters evaluated. It can be concluded that dry leaf extracts of jatropha may interfere on the initial development of wheat, indicating possible allelopathic action.

Table 3. Germination and seedling growth of wheat cultivar (Triticum aestivum L.) Frontana germinated and grown in substrate containing crude aqueous extract (EBA) autoclaved and non autoclaved leaves of Jatropha curcas.

\begin{tabular}{lcccc}
\hline Treatments & $\% \mathrm{G}$ & GSI & Length root $(\mathrm{cm})$ & Length shoot $(\mathrm{cm})$ \\
\hline Control & $91 \mathrm{a}$ & $21.74 \mathrm{a}$ & $11.07 \mathrm{~b}$ & $13.67 \mathrm{a}$ \\
$5 \%$ & $90 \mathrm{a}$ & $21.10 \mathrm{a}$ & $10.90 \mathrm{~b}$ & $14.62 \mathrm{a}$ \\
$10 \%$ & $89 \mathrm{a}$ & $20.53 \mathrm{a}$ & $12.90 \mathrm{a}$ & $15.30 \mathrm{a}$ \\
$15 \%$ & $85 \mathrm{a}$ & $20.05 \mathrm{a}$ & $13.87 \mathrm{a}$ & $14.77 \mathrm{a}$ \\
EBA & $89 \mathrm{a}$ & $20.06 \mathrm{a}$ & $8.85 \mathrm{~b}$ & $3.65 \mathrm{c}$ \\
$5 \%$ autoclaved & $73 \mathrm{~b}$ & $12.96 \mathrm{~b}$ & $10.70 \mathrm{~b}$ & $10.97 \mathrm{~b}$ \\
$10 \%$ autoclaved & $75 \mathrm{~b}$ & $14.24 \mathrm{~b}$ & $11.17 \mathrm{~b}$ & $12.62 \mathrm{~b}$ \\
$15 \%$ autoclaved & $71 \mathrm{~b}$ & $13.78 \mathrm{~b}$ & $10.87 \mathrm{~b}$ & $10.27 \mathrm{~b}$ \\
EBA autoclaved & $77 \mathrm{~b}$ & $12.84 \mathrm{~b}$ & $9.45 \mathrm{~b}$ & $5.15 \mathrm{c}$ \\
\hline C.V. $(\%)$ & 8.09 & 9.41 & 13.36 & 10.27 \\
\hline
\end{tabular}

C.V. = coefficient of variation; $\% \mathrm{G}=$ germination percentage; $\mathrm{GSI}=$ germination speed index.

Means comparisons within each column were compared by Scott-Knott test at $5 \%$ probability.

\section{Literature Cited}

Alves, J.M.A.; Sousa, A.A.; Silva, S.R.G; Guido N.L.; Smiderle, O.J. \& Uchôa, S.C.P.

2008. Pinhão-Manso: Uma alternativa para produção de biodiesel na agricultura familiar da amazônia brasileira. Agro@mbiente On-line, Boa Vista, 2 (1): 57-68.

Beltrão, N.E.M. \& Oliveira, M.I.P.

2008. Oleaginosas e seus Óleos: Vantagens e Desvantagens para Produção de Biodiesel. Campina Grande: EMBRAPA ALGODÃO. (Embrapa Algodão. Documentos, 201). 28 p.

Bonamigo, T.; Siberte, P.S.S.; Da Silva, J.; Poliszuk, M.C.C. $\&$ Fortes, A.M.T.

2009. Efeito alelopático do extrato de raiz de pinhão-manso na germinação e desenvolvimento inicial de soja e canola. In: XII Congresso Brasileiro de Fisiologia Vegetal, Fortaleza, 2009. Disponível em: http://www.sbfv.org.br/congresso2009/trabalhos/tema/metabolismo/-1088.pdf. Acesso em: 10/05/2012.

Chou C.H.

1983. Allelopathy in agroecosystems in Taiwan. In: Chou,Ch-H e Waller, G.R. (eds.), Allelochemicals and Pheromones. Taipei/Taiwan: Academia Sinica Monograph Series $N^{\circ}$, pp. 27-64.

Cruz-Silva, C.T.A.; Santorum, M. \& Bini, F.V.

2009. Efeito alelopático de extratos aquosos de Senecio brasiliensis (Spreng) Less sobre a germinação e o desenvolvimento de plântulas. Cultivando o Saber, Cascavel, 2 (1), pp. 62-70.

Cruz-Ortega, R.; Anaya, A.L. \& Ramos, L.

1988 Effects of allelopathic compounds of corn pollen on respiration and cellular division of watermelon. Journal of Chemical Ecology, 14: 71-76.
Devappa, R.K.; Maes, J. Makkar, H.P.S. Greyt, W. \& Becker, K. 2010. Quality of Biodiesel Prepared from Phorbol Ester Extracted Jatropha curcas Oil. J Am Oil Chem Soc, 87: 697-704.

Duke S.O. \& Dayan, F.E.

2006. Mode of action of phytotoxins from plants. In: Reigosa MJ, Pedrol N, González L (eds.), Allelopathy: A Physiological Process with Ecological Implications. Springer, Dordrecht, pp. 511-536.

Einhellig, F.A.

1995. Allelopathy. Current status and future goals. In: Inderjit, Dakshini, K. M. M; Einhellig, F. A. (eds.), Allelopathy. Organisms, Processes and Applications, New York: American Chemical Societies, Series 582, pp. 1-24.

Ferreira, A.G. \& Aquila, M.E.A.

2000. Alelopatia: uma área emergente da ecofisiologia. Revista Brasileira de Fisiologia Vegetal, 12: 175-204.

Ferreira, A.G. \& Borguetti, F.

2004. Germinação: do básico ao aplicado. Porto Alegre: Artmed, $323 \mathrm{p}$.

França, A.C.; Souza, I.F.; Santos, C.C.; Oliveira, E.Q. \& Martinotto, C.

2008. Atividades alelopáticas de nim sobre o crescimento de sorgo, alface e picão-preto. Ciência e Agrotecnologia, Lavras, 32 (5): 1374-1379.

Lemos, J.M.; Meinerz, C.C.; Bertuol, P.; Corteze, O. \& Guimarães, V.F.

2009. Efeito alelopático do extrato aquoso de folha de pinhão manso (Jatropha curcas L.) sobre a germinação e desenvolvimento inicial de alface (Lactuca sativa cv. Grand Rapids). Revista Brasileira de Agroecologia, Cruz Alta, 4 (2): 2529-2532. 
Maraschin-Silva, F. \& Áqüila, M.E.A.

2005. Potencial alelopático de Dodonaea viscosa (L.) Jacq. Iheringia - Série Botânica, Porto Alegre, 60: 91-98.

Melo, J.T. \& Gonçalves, A.N.

2001. Inibidores de germinação em frutos e sementes de pequi. Bol. Pesq. Desenv. Embrapa Cerrados, Planaltina 23: 1-11.

Muniz, F.R.; Cardoso, M.G.; Pinho, E.V.R. \&Vilela, M.

2007. Qualidade fisiológica de sementes de milho, feijão, soja e alface na presença de extrato de tiririca. Revista Brasileira de Sementes, Londrina, 29 (2): 195-204.

Pereira, M.R.R.; Teixeira, R.N.; Souza, G.S.F.; Silva, J.I.C. \& Martins, D.

2011. Inibição do desenvolvimento inicial de plantas de girassol, milho e triticale por palhada de capim-colchão. Planta Daninha, Viçosa, 29 (2): 305-310.

Periotto, F.; Perez, S.C.J.G.A. \& Lima, M.I.S.

2004. Efeito alelopático de Andira humili Mart. ex Benth na germinação e no crescimento de Lactuca sativaL. e Raphanus sativus L. Acta Botanica Brasilica, São Paulo, 18 (3): 723-730.

\section{Rice, E.L.}

1984. Allelopathy. Orlando: Academic Press. 422 p.

Sausen, T.L.; Löwe, T.R.; Figueiredo, L.S. \& Buzatto, C.R.

2009. Avaliação da atividade alelopática do extrato aquoso de folhas de Eugenia involucrata DC. e Acca sellowiana (O. Berg) Burret. Polibotánica, México, 27: 145-158.

Silva-Candido, A.C.; Schmidt, V., Laura, V.A.; Faccenda, O.; Hess, S.C, Simionatto, E. \& Peres, M.T.L.P.

2010. Potencial alelopático da parte aérea de Senna occidentalis (L.) Link (Fabaceae, Caesalpinioideae): bioensaios em laboratório. Acta Botanica Brasilica, São Paulo, 24 (1): 235-242.

Silva, H.L.; Trezzi, M.M.; Marchese, J.A.; Buzzello, G. Miotto Jr., E.; Patel, F.; Debastiani, F. \& Fiorese, J.

2009. Determinação de espécie indicadora e comparação de genótipos de girassol quanto ao potencial alelopático. Planta Daninha, Viçosa, 27 (4): 655-663.

Silva, V.S.; Silva Candido, A.C.; Muller, C.; Laura, V.A.; Faccenda, O.; Simionatto, E.; Hess, S.C. \& Peres, M.T.L.P.

2011. Potencial fitotóxico de Dicranopteris flexuosa (Schrad.) Underw. (Gleicheniaceae). Acta Botanica Brasilica, São Paulo, 25 (1): 95-104. 